\title{
MENURUNKAN KECEMASAN BELAJAR SANTRI BARU MELALUI BIMBINGAN DAN KONSELING
}

\author{
Elif Hudayana ${ }^{1}$, Chaerul Jannah ${ }^{2}$, Adha Siti Hartinah ${ }^{3}$, Muhamad Rifa'i Subhi ${ }^{4}$ \\ ${ }^{1}$ IAIN Pekalongan, 2 IAIN Pekalongan, ${ }^{3}$ IAIN Pekalongan, ${ }^{4}$ STIT Pemalang \\ E-mail: elifhudayana@gmail.com; chaeruljanah86@gmail.com; adhasahab1998@gmail.com; \\ muhamadrifaisubhi@yahoo.co.id
}

\begin{abstract}
.
This research intend to describe about anxiety experienced by the new students of Islamic Boarding School Al-Hadi Pekalongan. The scope of this research there are objective anxiety and neurotic anxiety. The method who used inthis research is Qualitative Descriptive and using Miles and Huberman's data analysis techniques. This research shows that the new student of Islamic Boarding School Al-Hadi Pekalongan have free floating neurotic anxiety. In this case, student revealed that himself often experienced anxiety to something not real. The student get the expectation, however accompanied also with anxiety or can be called anxious. This anxiety is named a free floating neurotic anxiety. The role of guidance and counseling to lowered the anxiety learning of new student is trough cognitive counseling. Cognitive counseling emphasize to counselee belief so that able to change negatif thinking and maladaptif thinking to be positif thinking and adaptif thinking. Trough this positif thinking the anxiety learning student will be come down even disappear.
\end{abstract}

Keywords : anxiety learning, student, guidance and counseling.

Open Access

Received : 2018-06-26. Published : 2020-01-30.

This is an open access article distributed under the terms of the Creative Commons Attribution 4.0 International License

Website: http://ejournal.umpri.ac.id/index.php/fokus

\section{PENDAHULUAN}

Salah satu upaya pemerintah untuk melepaskan masyarakat dari belenggu problem kehidupan yaitu dengan mewajibkan pendidikan bagi warganya. Tidak hanya pendidikan formal, para pemuka agama juga turut memprakarsai pendidikan berbasis agama dengan mendirikan pondok pesantren. Pondok pesantren yaitu suatu lembaga pendidikan Islam Indonesia yang bersifat tradisional untuk mendalami ilmu keagamaan Islam dan mengamalkannya sebagai pedoman hidup sehari-hari atau disebut tafaqquh fi ad-din dengan penekanan pentingnya moral dalam hidup bermasyarakat (Lubis, 2007: 164)

Sebagai lembaga pendidikan Islam, kegiatan belajar tentu menjadi salah satu hal yang penting sebagai tolok ukur keberhasilannya. Belajar adalah perubahan tingkah laku yang relatif tetap yang terjadi karena latihan dan pengalaman (Mustaqim, 2001: 34). Dalam hal ini, tujuan belajar di pondok pesantren yaitu untuk mendalami ilmu keagamaan Islam dan kemudian mengamalkannya menjadi pedoman hidup. Akan tetapi tujuan ini tidak akan serta merta tercapai. 
Belajar sebagai suatu proses tidak dapat lepas dari faktor-faktor yang mempengaruhinya. Faktor ini dapat digolongkan menjadi dua jenis, yaitu faktor intern dan faktor ekstern (Slameto, 2010: 54). Faktor ekstern adalah faktor yang berasal dari luar individu, meliputi faktor lingkungan sosial dan lingkungan nonsosial. Sedangkan faktor intern yaitu faktor yang berasal dari dalam diri individu, seperti fisiologis dan psikologis (Sumadi, 2002: 233; Syah, 2014: 130). Keadaan psikologis individu yang tidak stabil atau dilanda kecemasaan ketika proses belajar dapat berdampak pada kegagalan pencapaian tujuan belajar. Kecemasan ini menjadi bagian dari problema belajar santri baru.

Kecemasan merupakan pengalaman subjektif yang tidak menyenangkan mengenai kekhawatiran atau ketegangan berupa perasaan cemas, tegang, dan emosi yang dialami oleh seseorang (Ghufron dan Risnawita, 2014: 143). Kecemasan ini juga dapat terjadi pada santri ketika belajar. Terlebih lagi bagi santri baru pondok pesantren. Kecemasan sejatinya diperlukan sebagai motivasi untuk mencapai tujuan. Namun, kecemasan ini tentu ada tarafnya sendiri yaitu selama tidak mengganggu individu yang bersangkutan. Jika kecemasan terus berlanjut dan mengganggu santri, kegiatan mengaji tidak akan berjalan dengan baik.

Terdapat beberapa penelitian terdahulu mengenai kecemasan belajar. Seperti halnya sebuah jurnal yang mengusung efektifitas senam otak untuk mengurangi kecemasan dan stres pada anak sekolah. Gerakan brain gym ini meringankan atau merelaksasi siwa yang terlibat dalam situasi belajar tertentu (Purwanto dkk, 2009: 81). Penelitian lain mengenai kecemasan belajar yaitu sebuah penelitian yang mencari korelasi antara kecemasan belajar dengan motivasi belajar siswa dalam sekolah formal. Hasilnya adalah tidak ada hubungan yang signifikan antara kecemasan dalam belajar dengan motivasi belajar siswa (Yanti dan Zikra, 2013: 287). Sedangkan pada lingkungan pendidikan non formal, penelitian tentang pendidikan kemandirian dilakukan di pondok pesantren. Penelitian ini mengungkapkan bahwa kemandirian santri yang ditemukan di lapangan dilakukan melalui hal-hal sederhana dalam aktivitas sehari-hari seperti mencuci piring (Sanusi, 2012: 133). Berdasarkan penelitian terdahulu tersebut, peneliti berusaha mengombinasikan antara kecemasan belajar dengan pendidikan non formal.

Freud (dalam Feist, 2010: 92) mengungkapkan bahwa kecemasan pada dasarnya merupakan pengalaman ketidakberdayaan: perasaan tidak berdaya untuk menangani kebutuhan-kebutuhan internal, tidak berdaya menanggulangi ancaman-ancaman dari luar dan isyarat-isyarat disintegrasi, dan tidak berdaya untuk mempertahankan kelangsungan hidup. Setiap situasi bahaya adalah suatu derivatif atau suatu representasi pengalaman kehilangan.

Freud (dalam Rufaedah, 2012: 52) menyebutkan bahwa kecemasan terdiri dari dua jenis, yaitu 1) kecemasan objektif (objective anxiety) yaitu reaksi terhadap persepsi bahaya eksternal. Sifatnya lebih rasional dan alami. Kecemasan ini hampir serupa 
dengan ketakutan. Kecemasan realistik yaitu perasaan yang tidak menyenangkan dan tidak spesifik terhadap suatu bahaya yang mungkin terjadi (Semiun, 2006: 89). 2) Kecemasan neurotik, yaitu kecemasan yang bersifat tidak rasional. Kecemasan neurotik dibagi menjadi tiga jenis: kecemasan bebas mengambang, fobia, dan kecemasan histeria. Orang yang menderita kecemasan bebas mengambang berada dalam kondisi yang disebut expectant dread. Freud menggambarkannya sebagai rasa cemas yang mengandung harapan, harap-harap cemas atau keinginan yang disertai rasa cemas. Orang dengan kecemasan jenis ini sangat mengantisipasi hal-hal terburuk dan mengartikan sesuatu yang muncul sebagai pertanda buruk (Rufaedah, 2012: 52).

Adler (dalam Ghufron dan Risnawita, 2014: 145) menyebutkan bahwa kecemasan dipengaruhi oleh 2 faktor, yaitu (1) pengalaman negatif pada masa lalu. Pengalaman ini merupakan hal yang tidak menyenangkan pada masa lalu mengenai peristiwa yang dapat terulang lagi pada masa mendatang, apabila individu tersebut mengalami situasi atau kejadian yang sama dan juga tidak menyenangkan, misalnya pernah gagal dalam tes. Hal tersebut merupakan pengalaman umum yang menimbulkan kecemasan siswa dalam menghadaapi tes. (2) Pikiran yang tidak rasional. Para psikolog memperdebatkan bahwa kecemasan terjadi bukan karena suatu kejadian, melainkan kepercayaan atau keyakinan tentang kejadian itulah yang menjadi penyebab kecemasan

Sementara itu, Locke (dalam Hamalik, 2001: 36) mengungkapkan teori psikologi klasik yaitu bahwa belajar adalah all learning is a process of developing or training of mind. Proses belajar dilakukan dengan menggunakan substansi dan sensasi. Pengembangan kekuatan mencipta, ingatan, keinginan, dan pikiran dengan melatihnya. Dengan kata lain, pendidikan adalah suatu proses dari dalam atau inner development. Tujuan pendidikan adalah self development atau self realization

Menurut Thorndike (dalam Hamalik, 2013: 39) menyebutkan teori belajar behavioristik, belajar diartikan sebagai proses perubahan tingkah laku sebagai akibat dari interaksi antara stimulus dan respons. Jika belajar merupakan pemberian stimulus dari seorang pengajar kepada siswanya, maka perilaku siswa setelah berlajar merupakan respon terhadap apa yang diberikan guru dalam proses pembelajaran.

Berbeda dengan teori belajar behavioristik, Winkle (dalam Tohirin, 2008: 72). teori belajar kognitif mengungkapkan bahwa belajar pada dasarnya merupakan peristiwa mental, bukan peristiwa behavioral (yang bersifat jasmaniah). Meskipun halhal yang bersifat behavioral tampak lebih nyata, namun hal itu adalah dorongan mental yang diatur oleh otak manusia. Jika seorang siswa bisa menulis setelah diberikan pembelajaran tulis-menulis, maka itu tidak hanya respon setelah diberikan stimulus oleh guru, melainkan dorongan kognitif anak untuk melakukan apa yang telah dipelajari.

Dari beberapa pengertian di atas dapat disimpulkan bahwa belajar adalah sebuah proses perubahan tingkah laku yang disadari oleh individu, yang terjadi karena 
adanya stimulus yang diberikan dan dimanifestasikan dalam sebuah respon yang dilakukan secara sadar. Sedangkan kecemasan belajar yaitu rasa takut, cemas, khawatir, tegang yang dialami oleh individu dalam proses belajar. Ruang lingkup dalam penelitian ini yaitu kecemasan objektif dan kecemasan neurotis. Dalam hal ini, peneliti merujuk kepada teori Freud (dalam Rufaedah, 2012: 52) mengenai kecemasan pada individu yang dibagi kepada dua jenis tersebut.

Bimbingan dan konseling menggunakan pendekatan terapi kognitif merupakan salah satu upaya yang efektif dalam menurunkan atau mereduksi kecemasan seorang individu dalam berbagai setting (Irawati, Subandi \& Kumolohadi, 2011; Asrori, 2016; Ireel, Elita \& Mishbahuddin, 2018). Hal ini memberikan peluang besar bahwa kecemasan belajar pada santriwati baru Pondok Pesantren Putri Al-Hadi Pekalongan dapat diturunkan melalui layanan konseling kognitif. Hal ini juga diperkuat bahwa kognisi berpengaruh besar terhadap emosi dan perilaku manusia (Adiputra \& Saputra, 2015).

\section{METODE PENELITIAN}

Metode penelitian yang digunakan yaitu penelitian kualitatif deskriptif. Peneliti melakukan penelitian langsung ke lapangan. Subyek dalam penelitian ini ialah santriwati baru Pondok Pesantren Putri Al-Hadi Pekalongan, dengan latar belakang pendidikan sebelumnya yang berbeda.

Metode pengumpulan data yang digunakan ialah dengan melakukan observasi di pondok pesantren tersebut, dan melakukan wawancara dengan beberapa santri pondok pesantren. Untuk memperkuat penelitian ini, peneliti juga melakukan wawancara dengan ketua pondok pesantren. Teknik analisis data yang digunakan ialah teknik analisis data model Miles and Huberman. Aktivitas dalam analisis data kualitatif dilakukan secara interaktif dan berlangsung secara terus menerus sampai tuntas, sehingga datanya sudah jenuh. Aktivitas dalam analisis data, yaitu data reduction, data display, dan conclusion drawing/verification (Sugiyono, 2016:246).

\section{HASIL DAN PEMBAHASAN}

Metode pengumpulan data dalam penelitian ini yaitu melalui observasi ke lapangan secara langsung dan wawancara kepada santri juga ketua Pondok Pesantren $\mathrm{Al}-$ Hadi. Data yang diperoleh dari metode observasi ini yaitu mengenai keadaan situasi dan kondisi lapangan. Dalam hal ini peneliti melakukan observasi langsung di Pondok Pesantren Al-Hadi yang beralamat di Panjang Wetan Gang 1 No. 35 A Pekalongan Utara. Pondok Pesantren Al-Hadi terletak di dalam gang. Pondok Pesantren tersebut berupa bangunan batu bata berlantai 2 dengan keadaan yang kurang rapih. Dengan jumlah santri yang mencapai seratus lebih, hanya ada belasan pengurus inti. Bangunan pondok putri ini memiliki 6 kamar dengan setiap kamar diisi lebih dari 30 anak.

Wawancara yang peneliti lakukan yaitu wawancara kepada ketua pondok putri 
dan dua santri putri. Santri ini merupakan santri baru yang memiliki latar belakang pendidikan yang berbeda. Kegiatan mengaji yang dilakasanakan Pondok Pesantren AlHadi meliputi (1) ngaji bandongan yaitu setelah ashar sampai menjelang maghrib; (2) ngaji sorogan Al-Qur'an setelah isya' sampai pukul 20.00 WIB; (3) ngaji diniyah pada pukul 20.00 WIB sampai 21.00 WIB; dan (4) ngaji sorogan kitab dari pukul 21.00 WIB sampai 22.00 WIB. Berdasarkan jadwal ngaji tesebut maka santri Pondok Pesantren Al-Hadi wajib berada di dalam lingkungan pondok selama jam pondok berlangsung. Mengenai sistem ngaji, hal ini bergantung masing-masing ustadz.

Dengan jadwal pondok yang demikian padat karena mayoritas santri Pondok Pesantren Al-Hadi adalah mahasiswa dan pelajar, pada awal masuk pondok banyak santri yang merasa kaget dengan lingkungan dan situasi baru. Santri yang pertama yaitu FN. Pada awal masuk pondok pesantren, FN mengaku masih sulit beradaptasi karena keadaan air pondok yang memiliki bau serupa besi. Bahkan FN sampai menggunakan air galon untuk menggosok gigi dan membawa bajunya kepada tukang laundry. FN sering merasa khawatir dan tegang apabila ia ditunjuk untuk menjawab pertanyaan atapun ketika setor hafalan. Karena rasa khawatir dan tegang tersebut, FN merasa gugup dan lupa apa yang sudah ia pelajari sebelumnya. Ia dilanda keringat dingin dan konsentrasi FN pun terganggu. Ia juga ingin kegiatan mengaji tersebut segera berakhir sehingga ia bisa terbebas dari ketegangan tersebut. Dari ciri-ciri ini dapat disimpulkan bahwa FN mengalami kecemasan belajar.

FN mengaku memiliki hambatan dalam menghafal. Ia harus berada di suasana yang sepi agar bisa hafal. Walaupun selama ini FN selalu lolos dari hukuman karena ia selalu bisa menghafal, FN masih terus merasa cemas. Ia sendiri sudah memiliki sugesti, jika ia tidak cemas maka akan terjadi hal buruk kepadanya. Sebaliknya, jika ia cemas maka FN justru akan mendapatkan nasib baik. Hal ini pun menjadikan FN terus cemas jika akan mengaji ataupun hafalan.

Santri yang ke dua yaitu AF. Meskipun berbeda kultur dengan teman-teman pondok, AF tidak merasakan perbedaan dan ia dapat beradaptasi dengan baik. Hal ini karena ia sudah mengalaminya ketika mondok dahulu. Dalam mendalami ilmu agama, AF merasa tidak kesulitan sebab mayoritas kitab yang dikaji di Pondok Pesantren AlHadi sudah pernah ia pelajari di pondok pesantrenya dahulu. Hanya ada beberapa kitab saja yang belum pernah ia jumpai. Selebihnya, AF hanya mengulang sehingga ia bisa lebih cepat hafal dari santri yang lain. Intinya adalah AF tidak merasakan kecemasan apapun di pondok saat ini.

Penelitian ini difokuskan pada jenis kecemasan yang dialami santri baru Pondok Pesantren Al-Hadi Pekalongan dan bagaimana peran Bimbingan dan Konseling dalam mengurangi kecemasan yang terjadi pada santri tersebut. Data yang diperoleh menggambarkan keadaan bahwa terdapat santri baru yang mengalami kecemasan dan ada pula yang tidak mengalaminya. Selain itu peneliti juga mendapatkan data bagaimana upaya ketua pondok untuk mengatasi problem kecemasan belajar santri. 
Berdasarkan hasil wawancara yang dilakukan dengan narasumber pertama, peneliti dapat menarik kesimpulan bahwa FN mengalami diagnosis kecemasan belajar neurotik bebas mengambang. Freud (dalam Rufaedah, 2012: 52) menggambarkannya sebagai rasa cemas yang mengandung harapan atau keinginan yang disertai rasa cemas. Seperti yang dialami FN pada saat awal masuk pondok pesantren yang mengharuskan FN untuk mengikuti semua kegiatan yang telah ditetapkan pihak pesantren. Kecemasan ini terjadi pada saat FN hendak menyetorkan hafalan, sedangkan ia merasa bahwa ia sangat lemah dalam hal menghafal, sehingga rasa cemas itu semakin kuat. Tidak hanya itu, FN juga memiliki sugesti irasional. Dalam keyakinannya, apabila ia cemas maka akan terjadi hal baik kepadanya. Begitu pula sebaliknya, apabila FN merasa santai menghadapi setor hafalan, justru ia akan melalui setoran tersebut dengan baik. Dengan sugesti yang kuat tersebut menjadikan FN cemas terus menerus.

Pemikiran FN yang irasional inilah yang dimaksudkan Freud sebagai kecemasan bebas mengambang. Freud (Rufaedah, 2012: 52) menjelaskan bahwa penderita kecemasan bebas mengambang akan mengartikan sesuatu yang terjadi kepadanya sebagai pertanda buruk. Keinginanya pun selalu disertai dengan rasa cemas. Seperti FN tadi, tiap kali FN menginginkan berhasil setor hafalan maka ia selalu merasa cemas terlebih dahulu.

Berbeda dengan FN, AF narasumber kedua tidak mengalami kecemasan belajar sedikitpun. Hal ini terjadi karena AF sudah terbiasa dengan atmosfer pesantren. Sebelum menjadi santri Pondok Pesantren Al-Hadi, AF sudah menjadi santri saat SMA. Selain karena berpengalaman, AF memiliki keyakinan yang kuat dan positif mengenai bagaimana ia harus beradaptasi dengan budaya baru pesantrennya. Pemikiran ini berdampak pada sikap AF dalam menjalankan kegiatannya sehari-hari. AF tidak mengalami kecemasan belajar.

Prayitno (dalam Sukitman, 2015: 19) mengatakan bahwa bimbingan dan konseling adalah pelayanan bantuan untuk peserta didik, baik secara perorangan maupun kelompok, agar mandiri dan berkembang dengan optimal dalam pribadi, bimbingan sosial, belajar dan karier melalui berbagai jenis layanan dan kegiatan pendukung berdasarkan norma-norma yang berlaku. Berdasarkan data yang diperoleh peneliti saat melakukan wawancara terhadap ketua pondok, M mengaku bahwa upaya pihak pengurus pondok dalam mengatasi kecemasan belajar yaitu dengan memanggil santri yang bersangkutan untuk diberikan dukungan dan arahan. Secara tidak langsung, pihak pondok telah memberikan layanan BK untuk santrinya.

Dalam dunia bimbingan dan konseling, terdapat berbagai pendekatan dan teknik yang bisa dilakukan untuk membantu menyelesaikan permasalahan konseli. Pada problem kecemasan belajar yang terjadi pada santri FN, konseling kognitif efektif untuk mengurangi kecemasan tersebut. Beck (dalam Sukitman, 2015: 66) mengatakan bahwa konseling kognitif adalah konseling yang berfokus pada wawasan yang 
menekankan pengakuan dan mengubah pikiran negatif dan maladaptif. Sehingga melalui pendekatan ini konseli dapat merubah pemikiran dan keyakinanya.

Beberapa tahapan konseling kognitif yang dapat ditempuh guna menurunkan kecemasan belajar pada santri tersebut adalah (1) membangun agenda yang bermakna untuk para santri; (2) menentukan dan mengukur intensitas mood para santri; (3) mengidentifikasi dan mereviu masalah yang ditunjukkan, dalam hal ini berkaitan dengan kecemasan belajar; (4) membangkitkan ekspektasi para santri dalam perlakuan; (5) mengajarkan para santri tentang konseling kognitif dan peran dari para santri tersebut; (6) menggali informasi tentang kesulitan para santri dan mendiagnosisnya; (7) menentukan tujan konseling, dalam hal ini adalah menurunnya kecemasan belajar; (8) memberikan tugas kepada para santri, baik tugas yang dapat dikerjakan secara langsung saat konseling dilaksnakan maupun tugas yang membutuhkan waktu dalam penyelesaiannya (seperti halnya tugas rumah); (9) merangkum sesi konseling kogintif; dan (10) meminta umpan balik dari para santri (Adiputra \& Saputra, 2015: 79-80).

Melalui tahapan konseling koginitif tersebut diharapkan dapat menurunkan kecemasan belajar secara optimal, sehingga problematika yang muncul dari para santriwati baru Pondok Pesantren Putri Al-Hadi Pekalongan dapat terminimalisir dengan baik. Hal ini dikarenakan berdasarkan beberapa hasil penelitian terdahulu, konseling dengan menggunakan pendekatan terapi kongitif terbukti efektif dalam menurunkan atau mereduksi kecemasan, baik pada santri, siswa maupun individu yang lain (Ireel, Elita \& Mishbahuddin, 2018; Shobabiya \& Prasetyaningrum, 2017; Fitri, 2017; Sari, 2016; Lestari, 2019; Putri, Lalis, Apriliana \& Subhi, 2018). Di mana dalam praktiknya, pengubahan pola pemikiran para santri yang irasional serta keyakinan yang maladaptif lebih difokkuskan.

\section{SIMPULAN}

Kecemasan belajar yaitu rasa takut, tegang, dan cemas yang dialami individu ketika belajar. Dalam hal ini, kecemasan yang dialami santri baru Pondok Pesantren Al-Hadi adalah kecemasan neurotik bebas mengambang. Hal ini terjadi karena faktor psikologis santri yang belum siap dengan lingkungan baru juga pemikiran irasionalnya yang menyebabkan santri berharap namun cemas. Latar belakang santri baru pun turut berperan dalam menentukan kecemasan. Santri yang sudah pernah mendalami ilmu agama akan merasa lebih mudah mengaji dibandingkan dengan santri baru yang sama sekali belum pernah belajar ilmu agama.

Untuk mengurangi kecemasan belajar pada santri, konseling dapat dilakukan melalui pendekatan konseling kognitif. Pendekatan ini fokus kepada pengubahan pola pemikiran konseli yang irasional serta keyakinan yang maladaptif sehingga menyebabkan kecemasan pada santri. Melalui tahapan konselingnya, secara perlahan kecemasan konseli dapat terkurangi. 


\section{DAFTAR PUSTAKA}

Adiputra, S., \& Saputra, W. N. E. (2015). Teori Dasar Konseling. Lampung: Aura Publishing.

Asrori, A. (2016). Terapi kognitif perilaku untuk mengatasi gangguan kecemasan sosial. Jurnal Ilmiah Psikologi Terapan, 3(1), 89-107.

Feist, Jess. Feist, Gregory J. (2010). Theories of Personality atau Teori Kepribadian. Jakarta: Salemba Humanika.

Fitri, H. U. (2017). Keefektifan Layanan Konseling Kelompok Teknik Kognitif Restrukturing dan Teknik Desensitisasi Sistematis untuk Mereduksi Kecemasan Akademik Siswa SMA Negeri 9 Palembang (Doctoral dissertation, Pascasarjana).

Hamalik, Oemar. (2013). Proses Belajar Mengajar. Jakarta: Bumi Aksara.

Irawati, D., Subandi, M. A., \& Kumolohadi, R. (2011). Terapi Kognitif Perilaku Religius untuk Menurunkan Kecemasan terhadap Kematian pada Penderita HIV/AIDS. Jurnal Intervensi Psikologi, 3(2), 169-186.

Ireel, A. M., Elita, Y., \& Mishbahuddin, A. (2018). Efektivitas layanan konseling kelompok teknik restrukturisasi kognitif untuk mereduksi kecemasan menghadapi ujian siswa smp di kota bengkulu. Consilia: Jurnal Ilmiah Bimbingan dan Konseling, 1(2), 1-10.

Lestari, N. G. (2019). Efektivitas Konseling Kognitif Perilaku dengan Teknik Restrukturisasi Kognitif untuk Mengurangi Kecemasan Peserta Didik saat Presentasi di MTS Ismaria Al-Qur'aniyyah Bandar Lampung Tahun 2018/2019 (Doctoral dissertation, UIN Raden Intan Lampung).

Lubis, Saiful Akhyar. (2007). Konseling Islami: Kyai dan Pesantren. Yogyakarta: Elsaq.

Mustaqim. (2001). Psikologi Pendidikan. Semarang: Pustaka Pelajar.

Nur, Gufron M. S, Rini Risnawita. (2014). Teori-Teori Psikologi. Jakarta: Ar-Ruz Media.

Purwanto, Setiyo., Widyaswati, Ranita., Nuryati. (2009). "Manfaat Senam Otak (Brain Gym) dalam Mengatasi Kecemasan dan Stress pada Anak Sekolah". Jurnal Kesehatan Vol.II No.1 hlm. 81-90.

Putri, A. M., Lalis, L., Apriliana, R., \& Subhi, M. R. I. (2018). Peningkatan Disiplin Belajar Santri Melalui Bimbingan dan Konseling. Journal of Innovative Counseling: Theory, Practice, and Research, 2(01), 27-34.

Rufaedah, Any. (2012). Freud Tentang Manusia: Sebuah Pengantar. Malang: Averroes Press.

Sanusi, Uci., (2012). "Pendidikan Kemandirian di Pondok Pesantren (Studi Mengenai Realitas Kemnadirian Santri di Pondok Pesantren al-Istiqlal Cianjur dan Pondok Pesantren Bahrul Ulum Tasikmalaya)". Ta'lim Vol.I No.2 hlm. 123-139.

Sari, W. D. (2016). Program Layanan Konseling untuk Mereduksi Kecemasan Akademik Peserta Didik Menggunakan Teknik Restrukturisasi Kognitif (Doctoral dissertation, Universitas Pendidikan Indonesia).

Semiun, Yustinus. (2006). Teori Kepribadian dan Terapi Psikoanalitik Freud. Yogyakarta: Kanisius.

Shobabiya, M., \& Prasetyaningrum, J. (2017). Konseling Kognitif Untuk Mengurangi Kecemasan Akademik Pada Siswa SMP Kelas 7.

Slameto. (2010). Belajar dan Faktor-Faktor yang Mempengaruhinya. Jakarta: Rineka Cipta.

Sugiyono. (2016). Metode Kualitatif dan Kuantitatif. Cetakan ke-23. Bandung: CV. Alfabeta. 
Menurunkan kecemasan belajar santri baru.....

Sukitman, Tri. (2015). Panduan Lengkap dan Aplikatif Bimbingan Konseling Berbasis Pendidikan Karakter. Yogyakarta: Diva Press.

Sumadi, Suryabrata. (2002). Psikologi Pendidikan. Jakarta: RajaGrafindo Persada. Syah, Muhibbin. (2014). Psikologi Pendidikan. Bandung: Remaja Rosdakarya.

Tohirin. (2008). Psikologi Pembelajaran Pendidikan Agama ISlam. Jakarta: Raja Grafindo Persada.

Yanti, Supri., Erlamsyah., Zikra., (2013). "Hubungan antara Kecemasan dalam Belajar dengan Motivasi Belajar Siswa”. Konselor Vol.II No.1 hlm. 1-6. 